\title{
Low-Severity Hydroprocessing to Stabilize Bio-oil: TechnoEconomic Assessment
}

\section{IJ Tews}

DC Elliott

August 2014

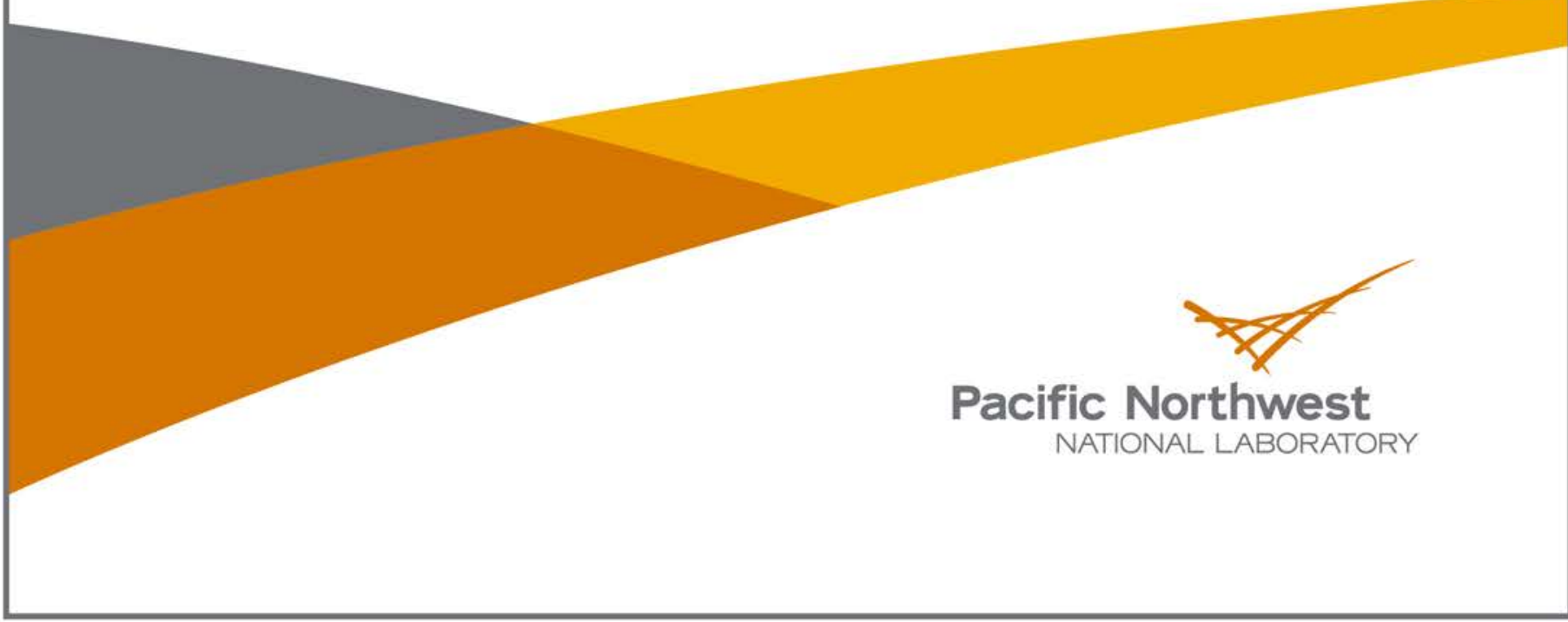




\title{
DISCLAIMER
}

This report was prepared as an account of work sponsored by an agency of the United States Government. Neither the United States Government nor any agency thereof, nor Battelle Memorial Institute, nor any of their employees, makes any warranty, express or implied, or assumes any legal liability or responsibility for the accuracy, completeness, or usefulness of any information, apparatus, product, or process disclosed, or represents that its use would not infringe privately owned rights. Reference herein to any specific commercial product, process, or service by trade name, trademark, manufacturer, or otherwise does not necessarily constitute or imply its endorsement, recommendation, or favoring by the United States Government or any agency thereof, or Battelle Memorial Institute. The views and opinions of authors expressed herein do not necessarily state or reflect those of the United States Government or any agency thereof.

\author{
PACIFIC NORTHWEST NATIONAL LABORATORY \\ operated by \\ BATTELLE \\ for the \\ UNITED STATES DEPARTMENT OF ENERGY \\ under Contract DE-AC05-76RL01830
}

Printed in the United States of America

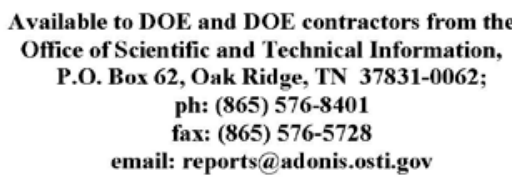

Available to the public from the National Technical Information Service, U.S. Department of Commerce, 5285 Port Royal Rd., Springfield, VA 22161 ph: (800) 553-6847 fax: $(703) 605-6900$

email: orders@ntis.fedworld.gov

online ordering: http://www.ntis.gov/ordering.htm

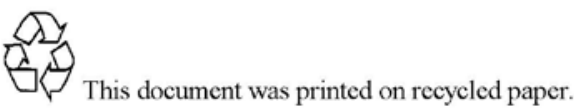

$(9 / 2003)$ 


\section{Low-Severity Hydroprocessing to Stabilize Bio-oil: TechnoEconomic Assessment}

IJ Tews

DC Elliott

August 22, 2014

Prepared for

the U.S. Department of Energy

under Contract DE-AC05-76RL01830

Pacific Northwest National Laboratory

Richland, Washington 99352 



\section{Contents}

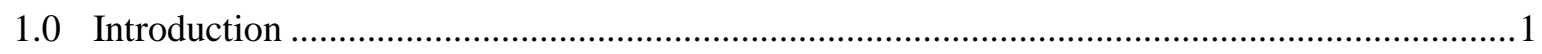

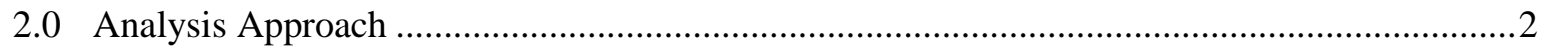

3.0 Process Design for Biomass Conversion to Liquids.............................................................

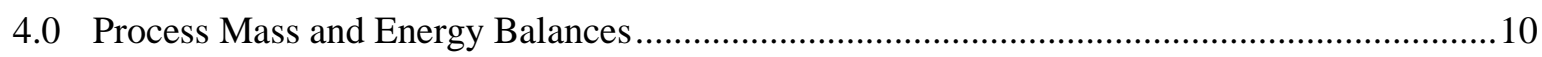

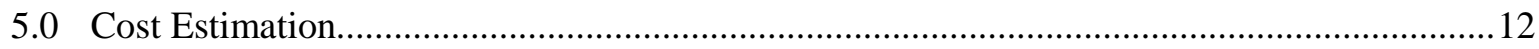

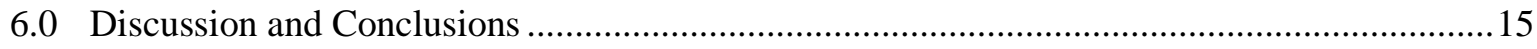

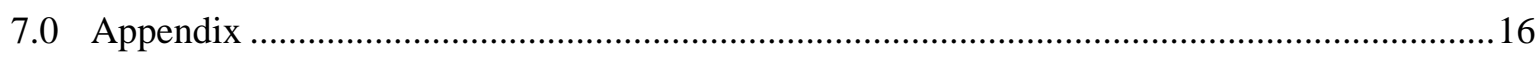

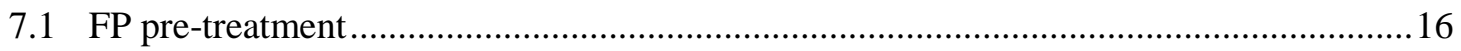

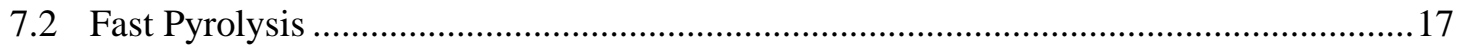

7.3 Fast pyrolysis bio-oil stabilization .......................................................................... 


\section{Glossary of Terms}

Fast pyrolysis - thermal conversion in the absence of oxygen at short residence time, for woody biomass typical conditions are $<2$ seconds at $\sim 500{ }^{\circ} \mathrm{C}$

Bio-oil - liquid product of fast pyrolysis

Hydroprocessing - chemical reaction with hydrogen gas, typically a catalytic process operated at elevated pressure, usually to remove heteroatoms, remove unsaturation, and reduce molecular weight.

Nth plant - commercial plant operating an established process, not a pioneer plant 


\subsection{Introduction}

The impetus for this study was the suggestion that recent developments in fast pyrolysis (FP) bio-oil production had indicated instability of the bio-oil in storage which might lead to unacceptable viscosity increases. Commercial operation of FP in Finland began in 2014 and the distribution of the bio-oil to isolated users has been proposed as the long-term plan. Stability of the shipped bio-oil therefore became a concern. Experimental results at PNNL with low-severity hydroprocessing of bio-oil for stabilization has validated a process in which the stability of the bio-oil could be improved, as measured by viscosity increase following storage of the product at $80^{\circ} \mathrm{C}$ for $24 \mathrm{~h}$.

In the work reported here the assessed process configuration consists of fast pyrolysis followed by low temperature and pressure hydroprocessing to produce a stable fuel oil product. The product could then be stored for an extended period of time without significant viscosity increase. This work was carried out as part of a collaborative project between Technical Research Centre of Finland (VTT) and Pacific Northwest National Laboratory (PNNL). The public funding agents for the work were Tekes in Finland and the Bioenergy Technologies Office of the U.S. Department of Energy. The effort was proposed as an evaluation of the process developed in earlier collaboration and jointly invented by VTT and PNNL researchers.

Based on previously conducted low-severity hydroprocessing experiments and the recent completion of a comparative TEA, ${ }^{1}$ an Aspen Plus ${ }^{\circledR}$ based model for the innovative low-severity hydroprocessing method to stabilize fast pyrolysis bio-oil was developed. Including the FP model from the comparative TEA, this model represents a complete standalone bio-oil production and stabilization plant. The assessed process configuration consists of fast pyrolysis (FP) followed by hydroprocessing to produce a stable fuel oil product, which could be stored on site for extensive periods of time, if necessary. Forest residue wood biomass was the feedstock used in the model.

The modeling effort described is an extension of the previously developed Biomass Direct Liquefaction comparative TEA. ${ }^{1}$ Specifically, models developed under that effort included FP and upgrading by multi-stage hydroprocessing and hydrothermal liquefaction and hydrotreating. In both cases the end product was a liquid hydrocarbon and not a stabilized oil, as is the case in this analysis. Modeling techniques, data assessment and economic analysis of all models was completed on the same basis such that all could be compared.

\footnotetext{
${ }^{1}$ Tews, I.J.; Onarheim, K., et al. Biomass Direct Liquefaction Options: TechnoEconomic Assessment. PNNLxxxxx, March 2014, Pacific Northwest National Laboratory, Richland, Washington.
} 


\subsection{Analysis Approach}

A technoeconomic assessment (TEA) is the standard tool for an investor in evaluating possible processing alternatives. The accuracy of this tool is dependent on the quality and reliability of the data at hand. Technoeconomic viability of process concepts, which haven't been demonstrated, is difficult to evaluate.

Aspen Plus ${ }^{\circledR}$ simulates steady-state chemical process reactions and calculates mass and energy balances based on user input. In this case the data used to establish operating conditions and conversion parameters was experimentally derived. Furthermore physical properties of the chemical compounds chosen to represent the reactants and products were provided by the Aspen Plus ${ }^{\circledR}$ thermodynamic database. Heat and material balances generated by the models were validated by PIs and then used to complete a TEA. Discrepancies in the energy balances are largely due to limitations of Aspen Plus ${ }^{\circledR}$ modeling software and specified physical property sets being used to calculate heats of reaction. The original use for this software is in the petrochemical industry which over many decades has a wellestablished knowledge of representative modeling components in several databases. The use of the software is this application wherein the heats of reaction for all the thermochemical processing steps of wood residue conversion have not been determined requires assumptions with uncertainties, which lead to error.

In order to model the FP technology, a model compound list needed to be defined to represent the products of the liquefaction step and also the low-severity hydroprocessed (stabilized) product. The organic products are a complex mixture of hundreds of compounds. The number and type of compounds used in the Aspen Plus ${ }^{\circledR}$ model to represent the organic liquid products must reasonably match several key properties such as elemental composition (C, H, O, N, S), quality based on GCMS data, density, and heating value. A significant effort and time was spent on development and refining of these lists in the previous study ${ }^{1}$ and these were used here.

The model compound list for FP bio-oil is shown in Table 1. These are for the most part commonly found components in bio-oil. However, each component also represents a group of similar components in real bio-oil. A user defined component, pyrolignin was created to allow for a better representation of biooil in Aspen Plus ${ }^{\circledR}$ since there is no lignin oligomer component in the Aspen data base.

Since the hydroprocessing step was low-severity, the chemical changes in the bio-oil were minimal and the same list of components could be used for the stabilized product.

Numerous technical assumptions were made in order to accomplish this modeling task due to the early stage of development of these biomass conversion technologies. Feedstock analyses used in the models were based on extensive research conducted on biomass material at VTT. Chipped forest residue was assumed as the raw material for the FP process. Table 2 shows the specification of the feedstock as a summary. Moisture content of the received biomass feedstock is assumed to be at $50 \%$. 
Table 1. Compounds Used to Model Fast Pyrolysis Bio-oil

\begin{tabular}{|l|c|c|c|c|c|c|c|}
\hline \multicolumn{1}{|c|}{ HTL OIL } & Wt\% & C & H & O & N & S & CAS \\
\hline Acetic Acid & $2.7 \%$ & 2 & 4 & 2 & & & $64-19-7$ \\
\hline Ethylene glycol & $0.1 \%$ & 2 & 6 & 2 & & & $107-21-1$ \\
\hline Acetol & $2.9 \%$ & 3 & 6 & 2 & & & $116-09-6$ \\
\hline Glycolaldehyde & $8.7 \%$ & 2 & 4 & 2 & & & $141-46-8$ \\
\hline Guaiacol & $11.4 \%$ & 7 & 8 & 2 & & & $90-05-1$ \\
\hline Furfural & $2.7 \%$ & 5 & 4 & 2 & & & $98-01-1$ \\
\hline Levoglucosan & $27.5 \%$ & 6 & 10 & 5 & & & $498-07-7$ \\
\hline Water & $28.7 \%$ & 0 & 2 & 1 & & & $7732-18-5$ \\
\hline Oleic Acid & $8.5 \%$ & 18 & 34 & 2 & & & $112-80-1$ \\
\hline ethylthioethanol & $0.1 \%$ & 4 & 10 & 1 & & 1 & $110-77-0$ \\
\hline 2-Pyrrolidone & $2.0 \%$ & 4 & 7 & 1 & 1 & & $616-45-5$ \\
\hline Pyrolignin & $4.7 \%$ & 24 & 32 & 4 & & & User Defined \\
\hline Total & $\mathbf{1 0 0 \%}$ & & & & & & \\
\hline
\end{tabular}

Table 2. Summary of Feedstock Properties Based on Dry Matter.

\begin{tabular}{|c|c|c|c|}
\hline \multicolumn{2}{|c|}{ Proximate Analysis, \% } & \multicolumn{2}{|c|}{ Ultimate Analysis, $\%$} \\
\hline Ash & 1.5 & Ash & 1.5 \\
\hline $\mathrm{FC}$ & 18.5 & $\mathrm{C}$ & 50.9 \\
\hline \multirow[t]{4}{*}{$\mathrm{VM}$} & 80.0 & $\mathrm{H}$ & 6.0 \\
\hline & & $\mathrm{N}$ & 0.3 \\
\hline & & $\mathrm{S}$ & 0.03 \\
\hline & & $\mathrm{O}$ & 41.3 \\
\hline
\end{tabular}

Size reduction and particle drying for FP is well understood. The plant capacity was set at processing a total of 2000 metric tons per day (474 MW HHV) of bone-dry biomass. This capacity was chosen such that the studies will be on a basis similar to those developed by the Bioenergy Technologies Office of U.S. Department of Energy. In the model, the 2000 metric tons per day are processed through four 500 mtpd reactor units for FP. The reactor size was based on literature reports and previous publications by Jones et al. regarding reactor size for fast pyrolysis. ${ }^{2}$ The plant is assumed to be an established " $\mathrm{n}$ " " plant design rather than a first of its kind (pioneer) plant.

Upgrading of the FP bio-oil product is still in the early stages of research \& development. The 3stage hydroprocessing model used in the earlier study for fast pyrolysis bio-oil upgrading to liquid hydrocarbon fuels was replaced in this model with a single-stage hydroprocessing at low-severity conditions (lower temperature and pressure with higher space velocity). The exothermic nature was not adequately modeled here, so that the full impact is not incorporated, but the low level of severity implies that the impact of the exothermic reactions will be minimal. A single stage of hydroprocessing for the FP bio-oil for stabilization has been tested in the laboratory, but there is no long-term validation of the method assumed here. The long-term catalyst lifetimes assumed here have not been demonstrated for the bio-oil hydroprocessing.

\footnotetext{
${ }^{2}$ Jones, S., P. Meyer, L. Snowden-Swan, A. Padmaperuma, E. Tan, A. Dutta, J. Jacobson, and K. Cafferty. 2013. "Process Design and Economics for the Conversion of Lignocellulosic Biomass to Hydrocarbon Fuels: Fast Pyrolysis and Hydrotreating Bio-oil Pathway,” PNNL-23053NREL/TP-5100-61178.
} 


\subsection{Process Design for Biomass Conversion to Liquids}

The process model developed in this study considered the following processing steps to all be included on-site: raw material preprocessing, pyrolysis, stabilization (low-severity hydroprocessing) and storage. Necessary hydrogen for stabilization is purchased instead of produced on-site due to the small quantities required. Heat input to the fast pyrolysis process is generated in the char combustor. In previous cases, integrated heating was explored for the stabilization/upgrading process steps. However, since the stabilization process used here will occur at lower temperatures heat integration was not considered in this model. Figure 1 shows the block diagram for the process. Fast pyrolysis reactor yields used to develop these models have been based on previously published experimental results ${ }^{3}$ by VTT. Stabilization reactor yields used in model development were based on experimental results, as well. ${ }^{4}$

\section{Biomass Pretreatment}

The first step in biomass pretreatment for the FP process is drying the feedstock from $50 \mathrm{wt} \%$ moisture as received to about $8-10 \mathrm{wt} \%$ moisture. This is done in a conventional belt dryer that can use a variety of energy sources, for instance, steam, hot water and electricity. Heat for the modeled dryer is generated in the char-fired boiler as steam and hot water. After drying, the biomass is ground to particle size $<5 \mathrm{~mm}$.

Raw material moisture strongly affects the product bio-oil moisture. The higher the bio-oil moisture, the lower is its heating value. As a consequence, raw material for the FP process must be dried to approximately 8-10 wt\% moisture in order to keep the bio-oil moisture below $30 \mathrm{wt} \%$, at which point phase separation occurs. The use of dried biomass also facilitates the fast heat-up in the pyrolysis process required for high bio-oil yield. The forest residue is also ground to a particle size of below $5 \mathrm{~mm}$. The small size is necessary in order to ensure complete reaction of the particle during the short residence time in the reactor.

\section{Fast pyrolysis}

Ground, dried biomass enters a circulating, fluidized-bed reactor and is rapidly heated to $520^{\circ} \mathrm{C}$ under atmospheric pressure in an oxygen-free environment. The reactor is heated with hot sand from the char combustor. After a biomass particle residence time of 1-2 seconds the resulting pyrolysis vapors, noncondensable gases, char and sand exit the reactor. Char and sand are separated directly after the reactor in cyclones and sent to the char-fired boiler where char is combusted and sand is re-heated. Pyrolysis vapors and non-condensable gases are sent to a quench tower. Vapors are quickly cooled and condensed at about $35^{\circ} \mathrm{C}$ in order to limit the rate of secondary and polymerization reactions in the bio-oil product. Condensed bio-oil is used as quenching medium in the quench tower. Non-condensable gases exit the quench tower in gas phase. Part of these gases are recycled to the reactor as fluidizing medium. The rest of the gases are flared without heat integration. Figure 2 shows the FP process that was modeled.

\footnotetext{
${ }^{3}$ Oasmaa, A. et al. Fast pyrolysis bio-oils from wood and agricultural residues. Energy Fuels, 2009 24:1380-1388. doi: 10.1021/ef901107f

${ }^{4}$ Oasmaa, A.; Elliott, D.C. Process for stabilizing fast pyrolysis oil and stabilized fast pyrolysis oil. patent application U.S. 2012/0285079 A1, November 15, 2012.
} 


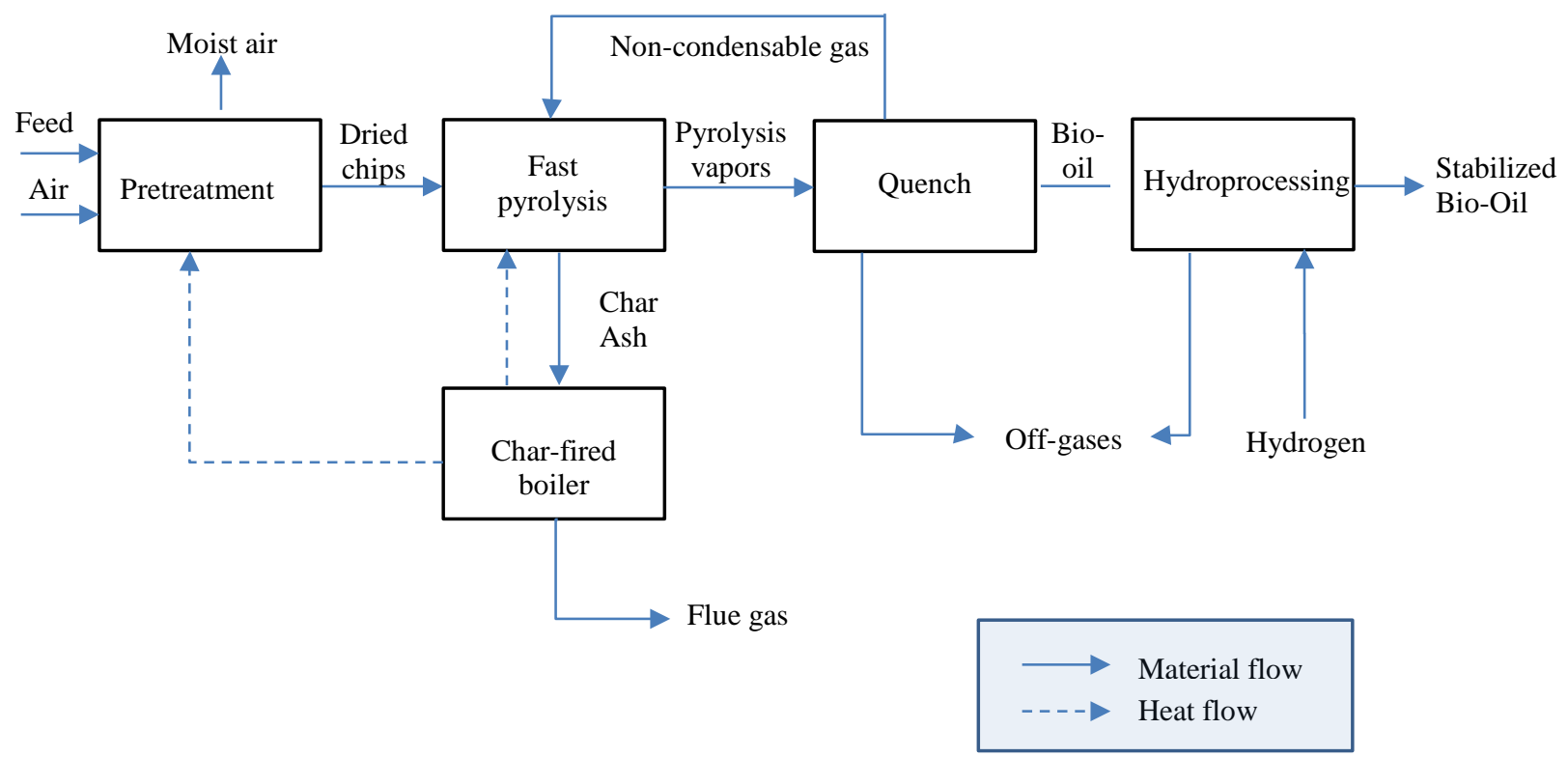

Figure 1. Fast pyrolysis and bio-oil stabilization process flow diagram

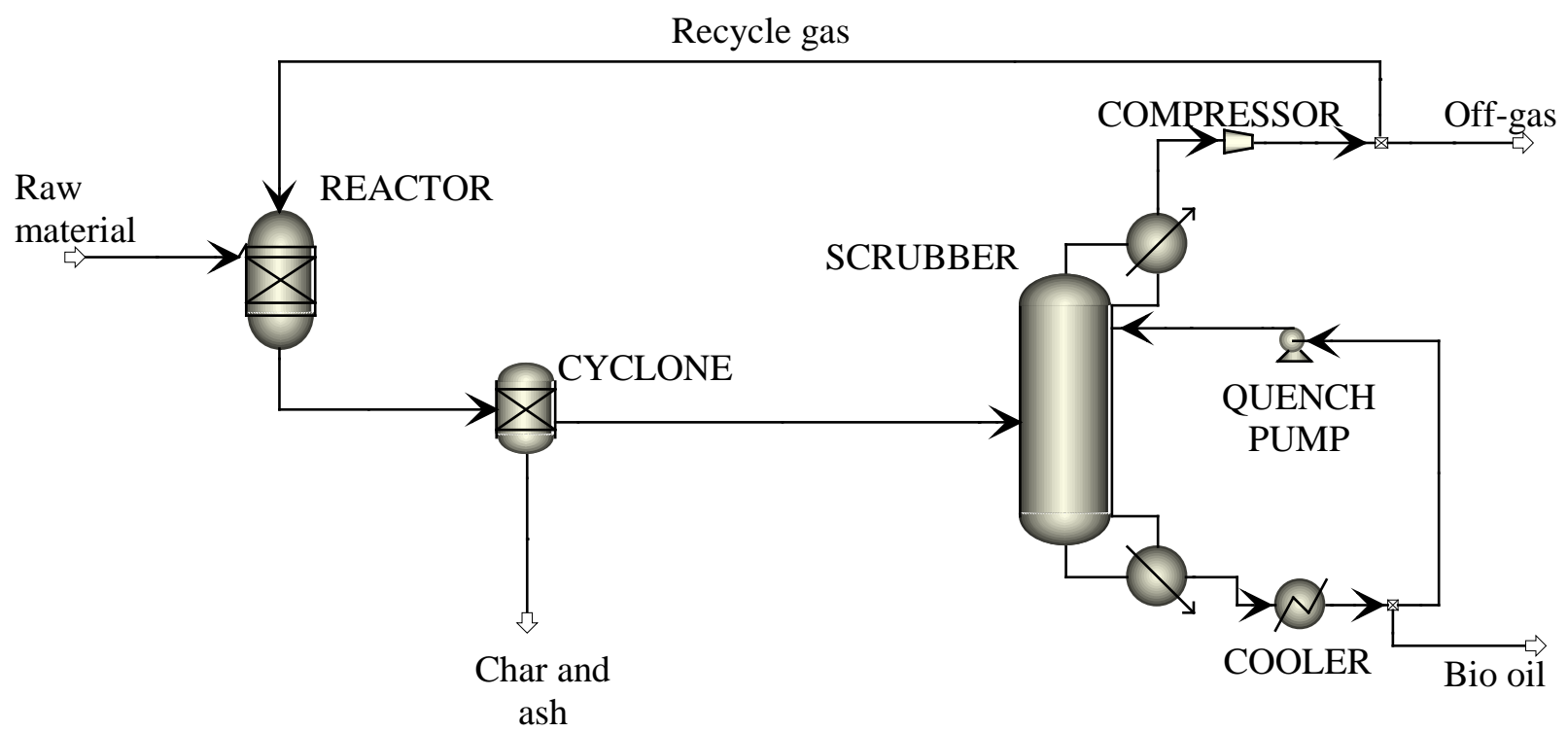

Figure 2 Unit Operations in the Fast Pyrolysis Plant

The fast pyrolysis products are detailed in Tables 1-3. 
Table 1. Fast Pyrolysis Yield, wt\% Based on Dry Biomass Feedstock

\begin{tabular}{|c|c|c|}
\hline Products & mass & carbon basis \\
\hline Bio-oil & 51.2 & 54.9 \\
\hline Char & 24.4 & 35.7 \\
\hline Water & 12.3 & 0 \\
\hline Gas & 12.1 & 9.4 \\
\hline
\end{tabular}

Table 2. Bio-oil Composition

\begin{tabular}{|c|c|}
\hline Bio-oil Components & $\mathrm{wt} \%$ \\
\hline Organic phase & 71.3 \\
\hline Water & 28.7 \\
\hline
\end{tabular}

Table 3. Gas Phase Composition

\begin{tabular}{|l|r|}
\hline Gas Component & mole \% \\
\hline $\mathrm{CO}_{2}$ & 32.5 \\
\hline $\mathrm{CO}$ & 43.0 \\
\hline $\mathrm{CH}_{4}$ & 12.0 \\
\hline $\mathrm{H}_{2} \mathrm{O}$ & 6.4 \\
\hline Ethylene & 4.7 \\
\hline Ethane & 1.4 \\
\hline
\end{tabular}

Bio-oil Stabilization

Bio-oil produced in the FP process is unstable and cannot be directly blended with conventional fossil fuels. For this model the bio-oil is put through a stabilization process where hydrogen is used to upgrade the unstable oil by low-severity hydroprocessing.

Liquids produced from biomass by FP are usually upgraded through a catalyzed reaction process where the oxygenated product is exposed to hydrogen under elevated pressure and high temperature. ${ }^{5}$ This process reduces the oxygen content via hydrodeoxygenation and decarboxylation reactions such that the resulting concentration is below $1 \%$ at severe processing conditions. The end result improves the overall value and usability of the finished product. Hydroprocessing is conducted in a continuous-flow, fixed-bed reactor packed with catalyst.

Low severity stabilization of the FP bio-oil is similar to the upgrading processes described above. However, for stabilization purposes the bio-oil is pumped to a lower pressure of $10 \mathrm{MPa}$ while being combined with compressed hydrogen. The liquid hourly space of 0.50 volume of oil per volume of catalyst bed per hour is used in this model. Processing at this higher than normal rate for bio-oil HDO

\footnotetext{
${ }^{5}$ Elliott, D.C. Historical Developments in Hydroprocessing Bio-oil. Energy Fuels 2007 21:1792-1815.
} 
occurs at a significantly lower temperature of $85{ }^{\circ} \mathrm{C}$ compared to $400{ }^{\circ} \mathrm{C}$ used for complete deoxygenation. This low-severity hydroprocessing method has been proven in lab scale experiments at PNNL. It is graphically presented in Figure 3. The water content of raw pyrolysis bio-oil from the earlier model and used here was higher (29\%) than the bio-oil actually used in the experimental tests for stabilization (22\%). Increasing the stabilized product moisture content to $34 \%$ is an acceptable assumption as some water formation occurred in the stabilization reaction. ${ }^{4}$ Water percentage is the first component of the product stream to be manipulated in order to achieve an elemental balance using Aspen Plus. The Solver Function in EXCEL is used to achieve a finished elemental balance based on the 10+ compounds used to represent the stream.

Since the FP bio-oil effluent temperature is close to the lower operating reaction temperature for hydroprocessing, integrated heating is not addressed in this model as it was in previous work. Minimal temperature increase is needed and accomplished by traditional heat exchangers. The bio-oil is only marginally changed in composition upon stabilization in the HT reactor. Experiments have shown that the bio-oil is sufficiently stable post single stage processing utilizing a Ru on carbon catalyst.

Although this plant does not include reforming of byproduct gases or natural gas but rather uses purchased $\mathrm{H}_{2}$, off-gas from the hydrotreater is still sent to a Pressure Swing Adsorption (PSA) system and $90 \%$ of hydrogen in the feed is assumed be recovered. This assumption is based on current cost information for a PSA unit, which can operate at this recovery efficiency. The recovered hydrogen is mixed with makeup hydrogen and compressed to feed back to the hydroprocessing reactor. The low pressure PSA tail gas stream is waste.

Stabilized bio-oil produced after hydrotreating comes out as a single phase product. Table 4 below indicates the composition of the product and gas phase on wt\% basis and carbon basis. Primary changes to the bio-oil composition occurred in the reduction of sugars such as levoglucosan, as well as some carbonyl compounds.

Table 4. Low Severity Stabilization Yield, wt\% and carbon basis

\begin{tabular}{|c|c|c|}
\hline Products & mass & carbon basis \\
\hline Stabilized Product & 96.8 & 94.9 \\
\hline Gas & 3.2 & 5.1 \\
\hline
\end{tabular}

Table 5. Bio-oil Composition wt.\%

\begin{tabular}{|c|c|}
\hline Bio-oil Components & wt\% \\
\hline Organic Phase & 66 \\
\hline Water & 34 \\
\hline
\end{tabular}


Table 6. Gas Composition, mole \%

\begin{tabular}{|c|c|}
\hline Gas Component & mole \% \\
\hline $\mathrm{CO}_{2}$ & 8 \\
\hline $\mathrm{CO}$ & 8 \\
\hline $\mathrm{CH}_{4}$ & 79 \\
\hline Ethylene & 3 \\
\hline Ethane & 3 \\
\hline
\end{tabular}




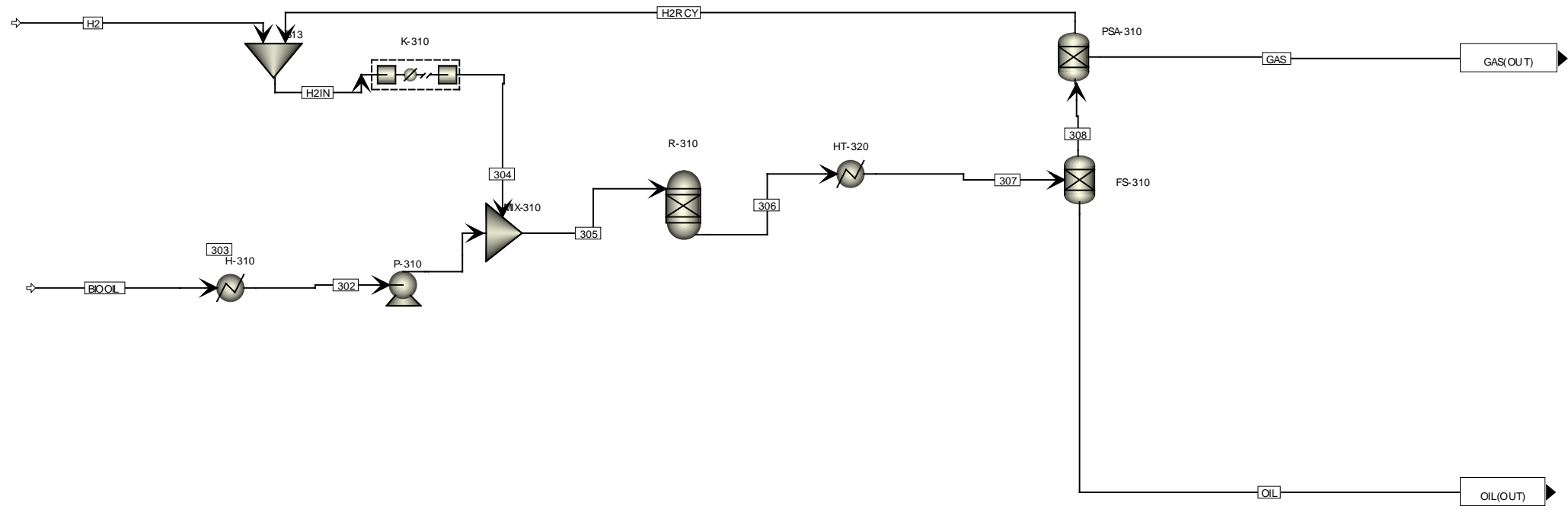

Figure 3. Hydroprocessing for bio-oil stabilization 


\subsection{Process Mass and Energy Balances}

Using Aspen Plus ${ }^{\circledR}$ models, overall mass and energy balance could be generated for the process. The model was based on relevant information including technical information from literature, as well as experimental values.

The mass balance for fast pyrolysis and bio-oil stabilization is depicted in Figure 4.

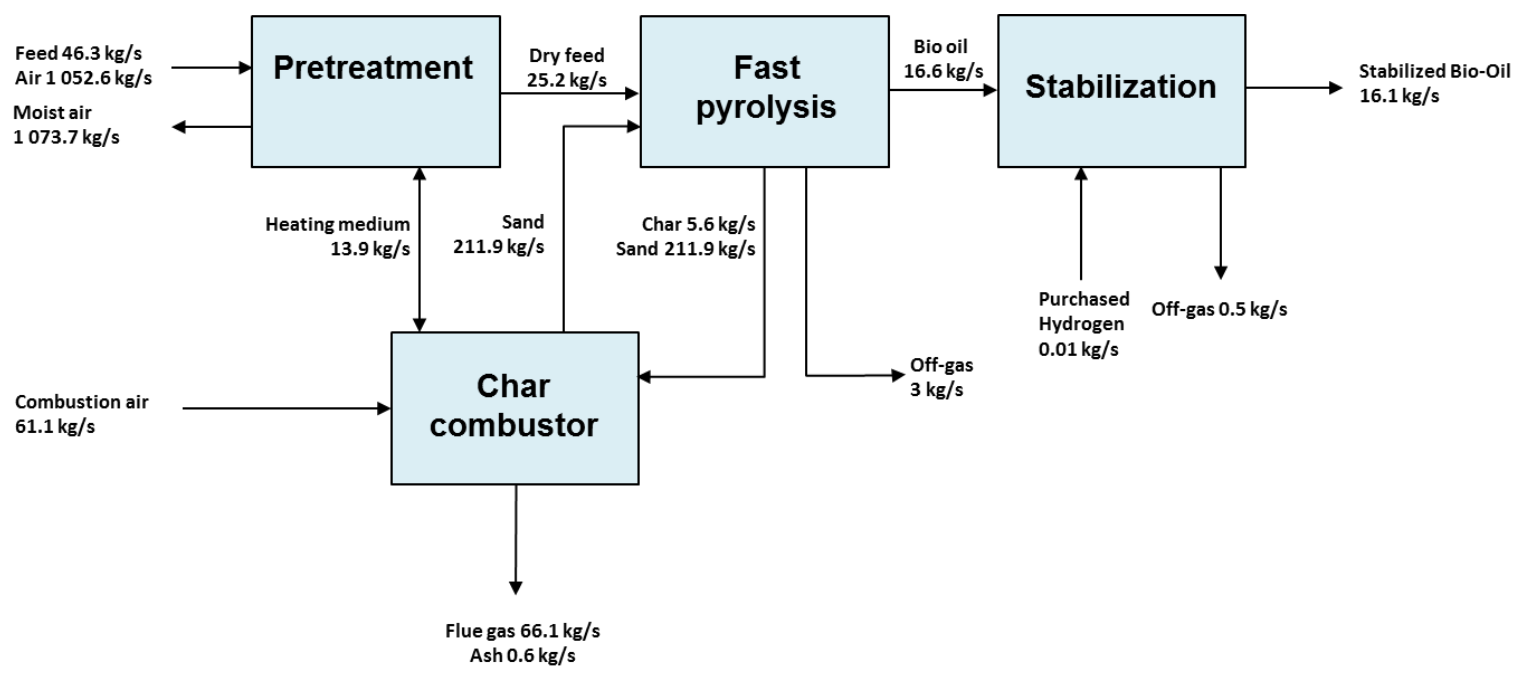

Figure 4. Mass Balance for the Fast Pyrolysis and Stabilization Process

The tabular form of the mass balance data for fast pyrolysis and bio-oil stabilization is given in Table 4. The overall mass balance for fast pyrolysis and stabilization shows a $64 \%$ yield $(16.1 / 25.2 \mathrm{~kg} / \mathrm{s})$ of stabilized bio-oil on the basis of the biomass fed to the FP unit.

Table 4. Mass Balance for the Fast Pyrolysis Pathway

\begin{tabular}{|l|l|r|}
\hline \multicolumn{1}{|c|}{ kg/s } & IN & OUT \\
\hline Wet forest residue & 46.3 & \\
\hline Combustion air & 61.1 & \\
\hline Purchased $\mathrm{H}_{2}$ & 0.01 & \\
\hline Stabilized Bio-Oil & & 16.1 \\
\hline Flue gas & & 66.1 \\
\hline Moisture & & 21.1 \\
\hline Off-gas & & 3.5 \\
\hline Ash & & 0.6 \\
\hline TOTAL & $\mathbf{1 0 7 . 4}$ & $\mathbf{1 0 7 . 4}$ \\
\hline
\end{tabular}


The energy balance for fast pyrolysis and bio-oil stabilization is depicted in Figure 5.

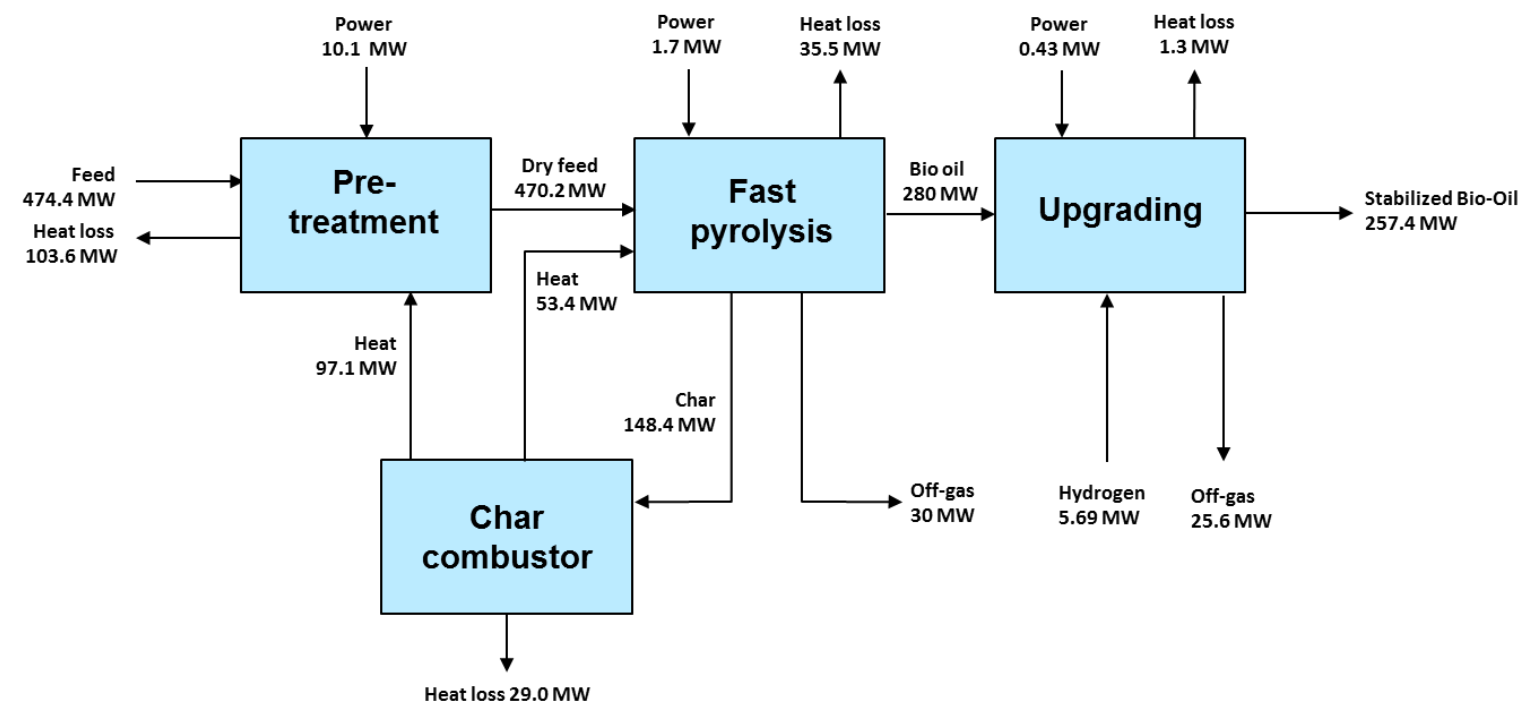

Figure 5. Energy balance (HHV basis) for Fast Pyrolysis and Bio-oil Stabilization

The overall energy balance for the FP process is off by 2\%. The energy balance discrepancies for individual blocks range from $0.01-5.0 \%$. It is believed that these are largely due to limitations of Aspen Plus ${ }^{\circledR}$ modeling software and specified physical property sets being used to calculate heats of reaction. The original use for this software is in the petrochemical industry with well-defined components. The use of the software in this application, wherein the heat of reaction for pyrolysis and for the hydrotreater as calculated in Aspen Plus ${ }^{\circledR}$ does not quite match experimental results and would need to be further investigated. Furthermore, the choice of compounds used to represent the bio-oil and stabilized bio-oil products and their heats of reaction are limited to classes of compounds and need better definition and detail.

The lower heating values for calculating the overall process efficiency for fast pyrolysis and bio-oil stabilization are given in Table 5 The overall energy efficiency of fast pyrolysis and bio-oil stabilization shows a 56.4\% yield of hydrocarbon liquids based on feed and power inputs. The power inputs are calculated by Aspen Plus ${ }^{\circledR}$ and are reported here without adjustment between electrical and thermal energy.

Table 5. Input and output for Low-Severity Hydrotreating of Fast Pyrolysis Bio-oil based on LHV

\begin{tabular}{|l|c|r|}
\hline & IN & OUT \\
\hline Feedstock & 387.5 & \\
\hline Power & 12.2 & \\
\hline & & \\
\hline Stabilized Bio-Oil & & 226.4 \\
\hline Off Gas & & 29.5 \\
\hline Heat loss & & 143.8 \\
\hline TOTAL & 399.7 & 399.7 \\
\hline
\end{tabular}




\subsection{Cost Estimation}

\section{Capital Equipment Costs}

The capital cost estimate is determined by aggregating individual equipment costs and applying factors. The equipment costs used in the economic analysis were developed from existing sources by extrapolation to appropriate scale of stream flow. Individual equipment costs were not developed within this study. The equipment cost estimates for fast pyrolysis were derived from Jones et al. ${ }^{2}$ (which used a $400 \mathrm{t} / \mathrm{d}$ reactor size) by adjusting the equipment based on the feed rate in this study (4 X $500 \mathrm{t} / \mathrm{d}$ ) using a 0.7 power factor. The uninstalled costs are the summation of equipment estimates. The installed costs (Fixed Capital Investment, FCI) are calculated from the equipment costs with a range of relevant factors applied for the different types of equipment by Jones et al. ${ }^{2}$ Installation factors used in the cost analysis of the equipment were obtained by several methods. Primary sources include Harris Group ${ }^{6}$, SRI PEP 2007 Yearbook $^{7}$ as well as Aspen Capital Cost Estimator. ${ }^{8}$ Values were either obtained directly or calculated based on equipment costs provided by the source.

\section{Production Costs}

Annual production cost is evaluated by adding operation and capital costs. Operation cost includes fixed and variable terms. Capital costs are estimated based on annuity.

Capital to be depreciated and used as part of production cost estimate is derived from the fixed installed capital investment ( FCI) costs (described above) by adding estimates for start-up costs (10\% of FCI), and interest during construction. A two year construction time is assumed.

Fixed operating costs include:

- $\quad$ operating labor (which is a function of plant size, 5 shifts assumed, 6 persons per shift)

- maintenance labor (1 \% of FCI assumed)

- $\quad$ overheads ( $2 \%$ of FCI assumed)

- maintenance materials (3 \% of FCI assumed)

- $\quad$ taxes, insurance (2\% of FCI assumed)

- $\quad$ other fixed costs ( $1 \%$ of FCI assumed)

Variable operating costs include:

- feedstock cost

- hydrogen gas

- electricity consumption

- catalyst costs

- waste handling

Parameters used in the assessment are summarized in Table 6 below. The higher than normal cost for hydrogen is based on a quote for delivered hydrogen in the small quantities required here.

\footnotetext{
${ }^{6}$ Dutta, A., Talmadge, M., Hensley, J., Worley, M., Dudgeon, D., Barton, D., Groenendijk, P., Ferrari, D., Stears, B., Searcy, E., Wright, C., Hess, J.R. 2011. Process design and economics for conversion of lignocellulosic biomass to ethanol: thermochemical pathway by indirect gasification and mixed alcohol synthesis. Golden, CO: National Renewable Energy Laboratory. http://www.nrel.gov/docs/fy11osti/51400.pdf

${ }^{7}$ SRI 2007. "Hydrogen production from natural gas ” PEP Yearbook, Vol 1E, SRI International, Menlo Park, California.

${ }^{8}$ http://www.aspentech.com/products/aspen-icarus-process-evaluator.aspx
} 
Table 6. Parameters used in economic assessment

\begin{tabular}{|l|c|l|}
\hline Feedstock forest residue cost & 30 & $\$ / \mathrm{t}(50 \%$ moisture) \\
\hline & 12.9 & $\$ / \mathrm{MWh}$ \\
\hline Electricity & 6.9 & $\mathrm{C} / \mathrm{kWh}$ \\
\hline Wastewater & 0.73 & $\$ / \mathrm{t}$ \\
\hline Labor rate & 0.05 & $\mathrm{M} \$ / \mathrm{a}$ \\
\hline Interest rate & 10 & $\%$ \\
\hline Service life & 20 & $\mathrm{a}$ \\
\hline Annuity & 0.1175 & \\
\hline Interest during construction & 11 & $\%$ \\
\hline Annual operating time & 7000 & $\mathrm{~h} / \mathrm{a}$ \\
\hline Ru/C catalyst & 132 & $\$ / \mathrm{kg}$ \\
\hline Hydrogen cost & 7 & $\mathrm{c} / \mathrm{SCF}$ \\
\hline
\end{tabular}

The capital costs are grouped into the subsections of the process and presented in Table 7 below.

Table 7. Fast Pyrolysis and Bio-oil Upgrading Capital Costs (millions of \$)

\begin{tabular}{|l|l|l|l|c|}
\hline Process Section & PID & Installed & Uninstalled & \\
\hline Feedstock Handling and Prep & A100 & $\mathbf{\$ 2 1 . 4}$ & $\mathbf{\$} 8.7$ & $8 \%$ \\
\hline Fast Pyrolysis & A100 & $\mathbf{\$ 2 1 0}$ & $\mathbf{\$} 61.9$ & $80 \%$ \\
\hline Hydroprocessing & A310 & $\$ 26.0$ & $\$ 10.5$ & $11 \%$ \\
\hline Utilities & A700 & $\$ 1.4$ & $\$ 1.0$ & $1 \%$ \\
\hline Total & & $\mathbf{\$ 2 5 9}$ & $\mathbf{\$ 8 2 . 1}$ & $\mathbf{1 0 0 \%}$ \\
\hline
\end{tabular}

A summary of the production cost estimate for the FP and stabilization case is shown in Table 8. The costs are given for both the primary FP step only, as well as FP combined with the additional fixed and variable costs for stabilization of the bio-oil. Catalyst replacement cost is indicated in the table also. The catalyst lifetime is assumed at one year. The total costs of the finished product, for both primary bio-oil production, as well as stabilized bio-oil production, are calculated in the bottom row. 
Table 8. Fast Pyrolysis production cost estimate

\begin{tabular}{|c|c|c|c|c|c|c|}
\hline & \multicolumn{3}{|c|}{ Fast Pyrolysis } & \multicolumn{3}{|c|}{ Stabilization } \\
\hline & $\mathrm{M} \$ / \mathrm{a}$ & $\$ / t$ & $\$ / G J$ & $\mathrm{M} \$ / \mathrm{a}$ & $\$ / t$ & $\$ / G J$ \\
\hline \multicolumn{7}{|l|}{ FIXED OPERATING COST } \\
\hline Operating labor & 1.1 & 3 & 0.2 & 0.3 & 1 & 0.1 \\
\hline Maintenance labor & 2.3 & 6 & 0.4 & 0.3 & 1 & 0.0 \\
\hline Overheads & 4.6 & 11 & 0.7 & 0.5 & 1 & 0.1 \\
\hline Maintenance materials & 7.0 & 17 & 1.1 & 0.8 & 2 & 0.1 \\
\hline Taxes, insurance & 4.6 & 11 & 0.7 & 0.5 & 1 & 0.1 \\
\hline Others & 2.3 & 6 & 0.4 & 0.3 & 1 & 0.0 \\
\hline Total & 22 & 52 & 3.5 & 2.8 & 7 & 0.5 \\
\hline \multicolumn{7}{|l|}{ MATERIAL COST } \\
\hline Purchased $\mathrm{H}_{2}$ & & & & 4.1 & 11 & 0.8 \\
\hline Stabilization catalyst & & & & 4.6 & 10 & 0.7 \\
\hline Total & & & & 8.7 & 21 & 1.5 \\
\hline \multicolumn{7}{|l|}{ VARIABLE OPERATING COST } \\
\hline Feedstock & 35.0 & 84 & 5.6 & 96.7 & 238 & 16.6 \\
\hline Electricity & 5.7 & 14 & 0.9 & 0.2 & 1 & 0.0 \\
\hline Total & 40.7 & 98 & 6.5 & 97.0 & 239 & 16.6 \\
\hline CAPITAL CHARGES & 34.0 & 81 & 5.5 & 4.0 & 10 & 0.7 \\
\hline PRODUCTION COST & 96.7 & 231 & 15.5 & 112.5 & 277 & 19.3 \\
\hline
\end{tabular}




\subsection{Discussion and Conclusions}

\section{$\underline{\text { Comparison of Fast Pyrolysis and Stabilization Costs }}$}

The driver behind the development of this cost model was to determine the additional expense of stabilization of fast pyrolysis bio-oil. The comparison of interest is the FP process alone and the FP process followed by the low-severity hydroprocessing to stabilize the bio-oil for long term storage. The comparison of efficiencies and costs are presented in Table 9.

Low-severity hydroprocessing of the FP bio-oil results in only a slight loss of energy efficiency compared to the FP process alone, as the majority of the material is recovered in the final liquid product. Low-severity hydroprocessing has a slightly higher investment in capital required with the inclusion of the hydroprocessing plant. The additional operating costs for the stabilization step are minor, but, overall, there is an increased cost for the stabilized bio-oil versus the raw bio-oil.

Table 9. Comparison of the Results for Fast Pyrolysis versus Stabilization

\begin{tabular}{|l|c|c|}
\hline & FP & FP + Stabilization \\
\hline Energy efficiency to liquid product, LHV & 60.2 & 58.4 \\
\hline Fixed Capital Investment, \$M & 232 & 259 \\
\hline Liquid product mass yield, \% feed, dry basis & 63.5 & 61.5 \\
\hline Liquid product cost, \$/GJ & 16.0 & 19.3 \\
\hline Liquid product cost, \$/metric ton & 231 & 277 \\
\hline
\end{tabular}

\section{Uncertainties Needing Further Research}

Hydrogen need in this processing plant would be minimal based on experimental data. As a result building a small scale hydrogen production facility would be unrealistic and purchasing the commodity would be preferable. In the previous model (2000 tpd Fast Pyrolysis and Upgrading) hydrogen was produced through reforming of process gases and natural gas. However, because capital investment would not be justified in contrast to the cost of purchased hydrogen, the production plant was not designed in this model. The byproduct gases from pyrolysis and upgrading need to be utilized effectively to improve the process economics and efficiency.

Discrepancies in the energy balances of the model are believed to be largely due to limitations of Aspen Plus ${ }^{\circledR}$ modeling software and specified physical property sets being used to calculate heats of reaction. The use of the software is this application wherein the heats of reaction for all the thermochemical processing steps of wood residue conversion have not been determined requires assumptions with uncertainties, which lead to error. More precise determination of this information will provide the more accurate data to improve the model. 


\subsection{Appendix}

The following sections provide the process diagrams and the data tables from the Aspen Plus ${ }^{\circledR}$ modeling of fast pyrolysis and bio-oil stabilization.

Note: Quantities in stream tables are for one train of 500 tDM/day

\subsection{FP pre-treatment}

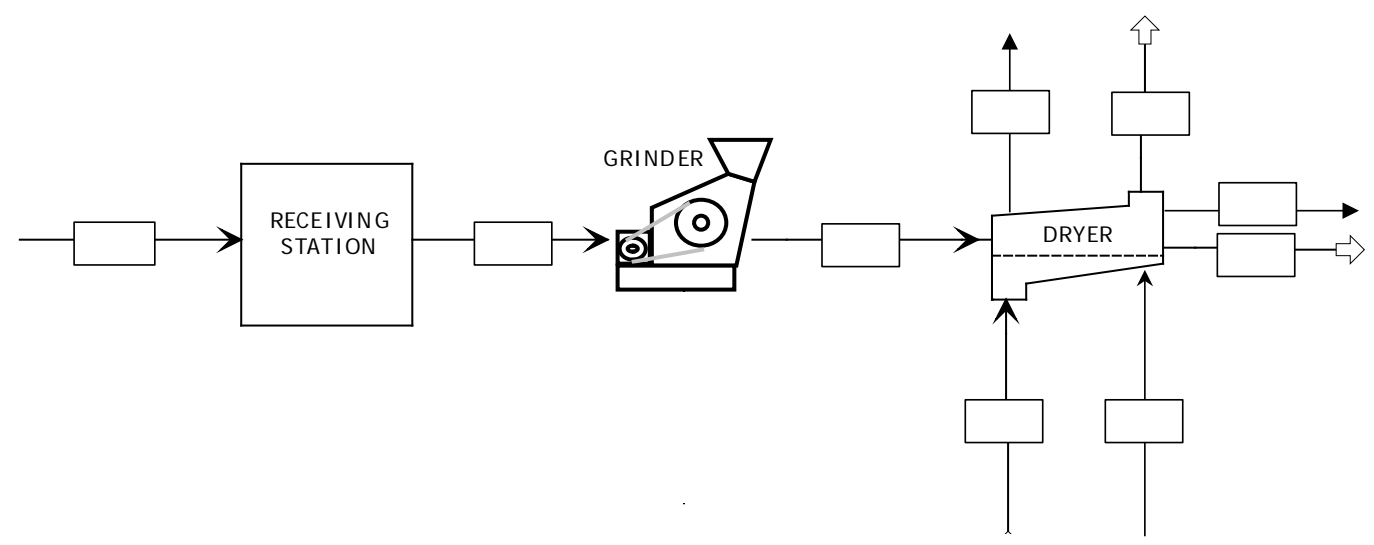

\begin{tabular}{|c|c|c|c|c|c|c|c|c|c|}
\hline Stream no. & 100 & 101 & 102 & 103 & 104 & 105 & 106 & 107 & 108 \\
\hline Temperature C & 25 & 25 & 25 & 25 & 0 & 25 & 25 & 127,4 & 120,3 \\
\hline Pressure bar & 1 & 1 & 1 & 1 & 1,01325 & 1 & 1 & 2 & 2 \\
\hline Vapor Frac & 0 & 0 & 0 & 0 & 1 & 1 & 0 & 1 & 0,8990334 \\
\hline Total Flow cu & $5,82 \mathrm{E}-03$ & $5,82 \mathrm{E}-03$ & $5,82 \mathrm{E}-03$ & $5,06 \mathrm{E}-04$ & 198,6225 & 207,2067 & $5,32 \mathrm{E}-03$ & 12,81183 & 11,31485 \\
\hline Enthalpy $\mathrm{J} / \mathrm{kI}$ & $-2,86 E+08$ & $-2,86 E+08$ & $-2,86 E+08$ & $-2,86 E+08$ & $-3,94 E+05$ & $-3,50 E+04$ & $-2,86 E+08$ & -238350000 & $-2,43 E+08$ \\
\hline Total Flow kg, & 20835 & 20835 & 20835 & 1811,739 & 947326,00 & 947326,00 & 19023,26 & 49900 & 49900 \\
\hline $\mathrm{H} 2 \mathrm{O}$ & 20835 & 20835 & 20835 & 1811,739 & 0 & 0 & 19023,26 & 49900 & 49900 \\
\hline N2 & 0 & 0 & 0 & 0 & 748387,00 & 748387,00 & 0 & 0 & 0 \\
\hline $\mathrm{O} 2$ & 0 & 0 & 0 & 0 & 198938,00 & 198938,00 & 0 & 0 & 0 \\
\hline Total Flow kg, & 41670 & 41670 & 41670 & 22646,74 & 947326,00 & 947326,00 & 19023,26 & 49900 & 49900 \\
\hline \multicolumn{10}{|l|}{ Substream: NC } \\
\hline \multicolumn{10}{|l|}{ Mass Flow $\mathrm{k} \xi$} \\
\hline WOOD & 20835 & 20835 & 20835 & 20835 & 0 & 0 & 0 & 0 & 0 \\
\hline
\end{tabular}




\subsection{Fast Pyrolysis}

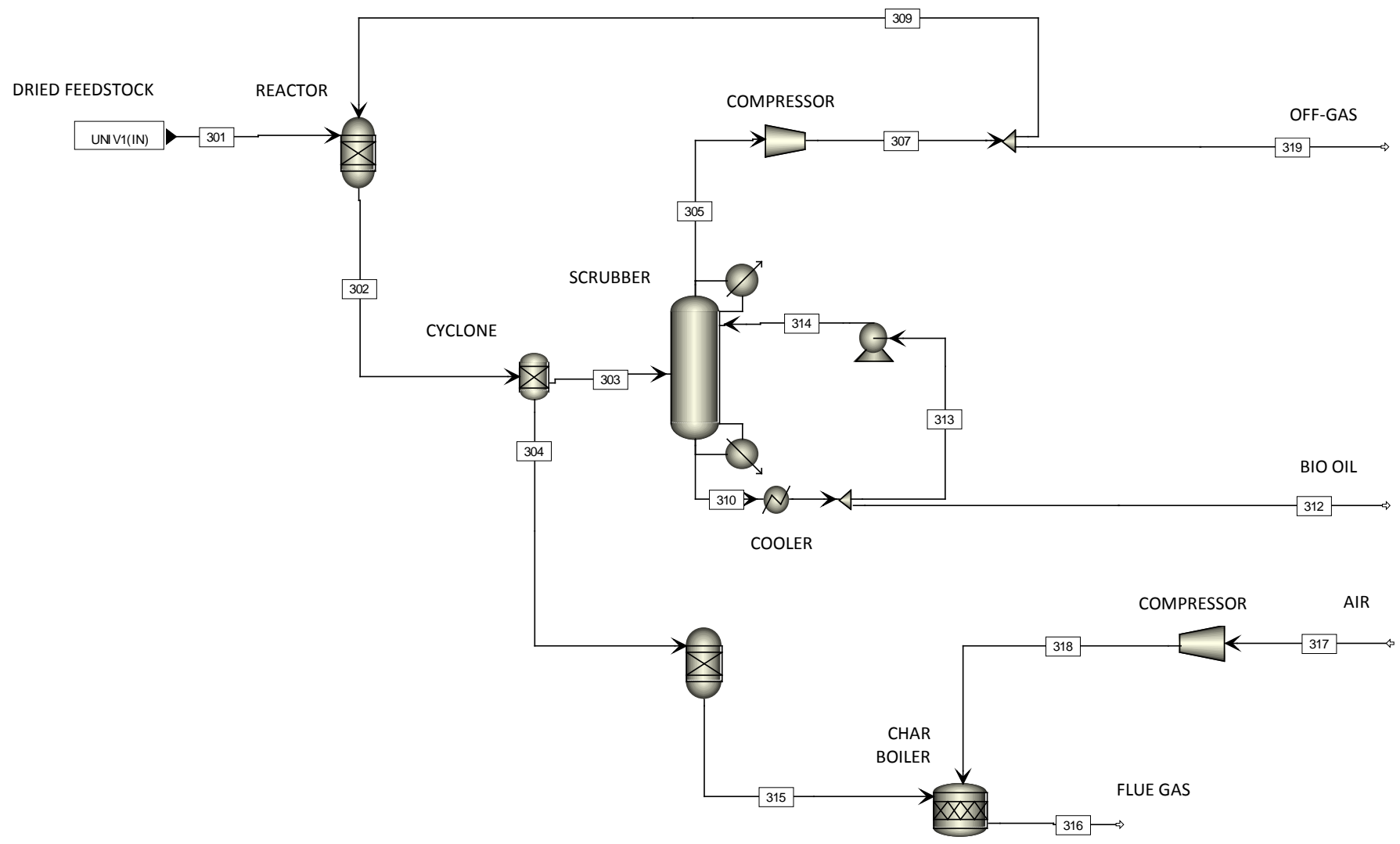




\begin{tabular}{|c|c|c|c|c|c|c|c|c|c|c|c|c|c|c|c|c|}
\hline & 301 & 302 & 303 & 304 & 305 & 307 & 309 & 310 & 312 & 313 & 314 & 315 & 316 & 317 & 318 & 319 \\
\hline Temperature C & 40 & 520 & 520 & & 40 & 65,94556 & 66,5525 & 60,81175 & 35 & 35 & 35,12746 & 480 & 1341,287 & 25 & 37,52781 & 66,5525 \\
\hline Pressure bar & 1,01325 & 1,01325 & 1,01325 & 1,01325 & 1,01325 & 1,2 & 1,2 & 1,01325 & 1,01325 & 1,01325 & 3 & 1,01325 & 1,01325 & 1,01325 & 1,09 & 1,2 \\
\hline Total Flow cum $/ \mathrm{sec}$ & $5,14 \mathrm{E}-04$ & 7,381634 & 7,369977 & 0 & 9,305353 & 8,508202 & 7,968344 & 0,1904098 & $3,32 \mathrm{E}-03$ & 0,1823651 & 0,1823872 & 1,510701 & 72,87562 & 12,99373 & 12,5877 & 0,5415748 \\
\hline Enthalpy $\mathrm{J} / \mathrm{kmol}$ & $-2,85 E+08$ & $-2,50 E+08$ & & & $-1,97 E+08$ & $-1,96 E+08$ & $-1,96 E+08$ & $-3,58 E+08$ & $-3,61 E+08$ & $-3,61 E+08$ & $-3,61 E+08$ & $1,37 E+07$ & $-2,63 E+07$ & $-6531,045$ & $3,59 \mathrm{E}+05$ & $-1,96 E+08$ \\
\hline Total Flow $\mathrm{kg} / \mathrm{hr}$ & 22646,74 & 22646,74 & 17569,7649 & 5076,974 & 40570,77 & 40570,77 & 37988,83 & $8,38 \mathrm{E}+05$ & 14988,61 & $8,23 E+05$ & $8,23 E+05$ & 5076,974 & 60494,31 & 55000 & 55000 & 2581,941 \\
\hline $\mathrm{C} 2 \mathrm{H} 4 \mathrm{O}-01$ & 0 & 403,4964 & 403,4964 & 0 & 79,6919 & 79,6919 & 74,62027 & 22287,8 & 398,4162 & 21889,39 & 21889,39 & 0 & 0 & 0 & 0 & 5,071626 \\
\hline C2H6O-01 & 0 & 19,21411 & 19,21411 & 0 & 0,0136091 & 0,0136091 & 0,012743 & 1074,895 & 19,21479 & 1055,68 & 1055,68 & 0 & 0 & 0 & 0 & $8,66 \mathrm{E}-04$ \\
\hline С3H6O-01 & 0 & 432,3176 & 432,3176 & 0 & 14,23302 & 14,23302 & 13,32723 & 24134,57 & 431,429 & 23703,14 & 23703,14 & 0 & 0 & 0 & 0 & 0,9057955 \\
\hline $\mathrm{C} 2 \mathrm{H} 4 \mathrm{O}-02$ & 0 & 1296,953 & 1296,953 & 0 & 18,17706 & 18,17706 & 17,02026 & 72492,53 & 1295,875 & 71196,66 & 71196,66 & 0 & 0 & 0 & 0 & 1,156796 \\
\hline С7H8O-01 & 0 & 1702,37 & 1702,37 & 0 & 1,976963 & 1,976963 & 1,851148 & 95227,71 & 1702,288 & 93525,42 & 93525,42 & 0 & 0 & 0 & 0 & 0,1258148 \\
\hline $\mathrm{C} 5 \mathrm{H} 4 \mathrm{O}-01$ & 0 & 401,575 & 401,575 & 0 & 38,77365 & 38,77365 & 36,30607 & 22327,48 & 399,1256 & 21928,36 & 21928,36 & 0 & 0 & 0 & 0 & 2,467571 \\
\hline LEVOGLUC & 0 & 4114,062 & 4114,062 & 0 & $2,51 \mathrm{E}-07$ & $2,51 \mathrm{E}-07$ & $2,35 \mathrm{E}-07$ & $2,30 E+05$ & 4114,336 & $2,26 \mathrm{E}+05$ & $2,26 \mathrm{E}+05$ & 0 & 0 & 0 & 0 & $1,60 \mathrm{E}-08$ \\
\hline $\mathrm{CO} 2$ & 0 & 1196,893 & 1196,893 & 0 & 18336,39 & 18336,39 & 17169,46 & 1677,977 & 29,99547 & 1647,981 & 1647,981 & 0 & 14456,8 & 0 & 0 & 1166,936 \\
\hline $\mathrm{CH} 4$ & 0 & 162,1525 & 162,1525 & 0 & 2542,921 & 2542,921 & 2381,088 & 17,72398 & 0,3168334 & 17,40714 & 17,40714 & 0 & 0 & 0 & 0 & 161,8325 \\
\hline $\mathrm{H} 2 \mathrm{O}$ & 1811,739 & 4381,867 & 4381,867 & 0 & 1524,35 & 1524,35 & 1427,34 & $2,40 E+05$ & 4285,122 & $2,35 E+05$ & $2,35 E+05$ & 0 & 1210,871 & 0 & 0 & 97,01026 \\
\hline N2 & 0 & 0 & 0 & 0 & $1,06 \mathrm{E}-03$ & $1,06 \mathrm{E}-03$ & 9,94E-04 & $1,63 \mathrm{E}-05$ & $2,91 \mathrm{E}-07$ & $1,60 \mathrm{E}-05$ & $1,60 \mathrm{E}-05$ & 12,501 & 43462,5 & 43450 & 43450 & $6,76 \mathrm{E}-05$ \\
\hline CO & 0 & 1007,404 & 1007,404 & 0 & 15749,84 & 15749,84 & 14747,51 & 283,1287 & 5,061201 & 278,0675 & 278,0675 & 0 & 0 & 0 & 0 & 1002,326 \\
\hline $\mathrm{H} 2$ & 0 & 0 & 0 & 0 & 0 & 0 & 0 & 0 & 0 & 0 & 0 & 123,2526 & 0 & 0 & 0 & 0 \\
\hline 02 & 0 & 0 & 0 & 0 & 0 & 0 & 0 & 0 & 0 & 0 & 0 & 843,1064 & 1049,103 & 11550 & 11550 & 0 \\
\hline NO & 0 & 0 & 0 & 0 & 0 & 0 & 0 & 0 & 0 & 0 & 0 & 0 & $2,50 \mathrm{E}-04$ & 0 & 0 & 0 \\
\hline $\mathrm{s}$ & 0 & 0 & 0 & 0 & 0 & 0 & 0 & 0 & 0 & 0 & 0 & 1,2501 & 0 & 0 & 0 & 0 \\
\hline $\mathrm{C} 2 \mathrm{H} 6-02$ & 0 & 35,3407 & 35,3407 & 0 & 552,2624 & 552,2624 & 517,1162 & 10,8462 & 0,1938864 & 10,65232 & 10,65232 & 0 & 0 & 0 & 0 & 35,14621 \\
\hline $\mathrm{C} 2 \mathrm{H} 4-02$ & 0 & 109,6413 & 109,6413 & 0 & 1711,89 & 1711,89 & 1602,945 & 38,84392 & 0,6943729 & 38,14954 & 38,14954 & 0 & 0 & 0 & 0 & 108,9454 \\
\hline 502 & 0 & 0 & 0 & 0 & 0 & 0 & 0 & 0 & 0 & 0 & 0 & 0 & 2,504319 & 0 & 0 & 0 \\
\hline $\mathrm{C} 18 \mathrm{H} 3-01$ & 0 & 1276,778 & 1276,778 & 0 & 0,0567176 & 0,0567176 & 0,053108 & 71431,17 & 1276,902 & 70154,27 & 70154,27 & 0 & 0 & 0 & 0 & $3,61 \mathrm{E}-03$ \\
\hline C4H10-01 & 0 & 16,55941 & 16,55941 & 0 & 0,1755143 & 0,1755143 & 0,1643445 & 925,6936 & 16,54768 & 909,1459 & 909,1459 & 0 & 0 & 0 & 0 & 0,0111698 \\
\hline C4H7N-01 & 0 & 303,8199 & 303,8199 & 0 & 0,0111301 & 0,0111301 & 0,0104218 & 16995,13 & 303,8045 & 16691,32 & 16691,32 & 0 & 0 & 0 & 0 & $7,08 \mathrm{E}-04$ \\
\hline PYROLIGN & 0 & 709,321 & 709,321 & 0 & $6,43 \mathrm{E}-15$ & $6,43 E-15$ & $6,02 \mathrm{E}-15$ & 39678,21 & 709,2866 & 38968,92 & 38968,92 & 0 & 0 & 0 & 0 & $4,09 \mathrm{E}-16$ \\
\hline Total Flow kg/hr & 1811,739 & 17569,76 & 17569,769 & 0 & 40570,77 & 40570,77 & 37988,83 & $8,38 E+05$ & 14988,61 & $8,23 E+05$ & $8,23 E+05$ & 980,1101 & 60181,78 & 55000 & 55000 & 2581,941 \\
\hline Substream: CISOLID & & & & & & & & & & & & & & & & \\
\hline \multicolumn{17}{|l|}{ Mass Flow $\mathrm{kg} / \mathrm{hr}$} \\
\hline C & 0 & 0 & 0 & 0 & 0 & 0 & 0 & 0 & 0 & 0 & 0 & 3784,339 & 0 & 0 & 0 & 0 \\
\hline \multirow{2}{*}{\multicolumn{17}{|c|}{$\begin{array}{l}\text { Substream: } \mathrm{NC} \\
\text { Mass Flow } \mathrm{kg} / \mathrm{hr}\end{array}$}} \\
\hline & & & & & & & & & & & & & & & & \\
\hline CHAR & 0 & 4764,449 & 0 & 4764,449 & 0 & 0 & 0 & 0 & 0 & 0 & 0 & 0 & 0 & 0 & 0 & \\
\hline ASH & 0 & 312,525 & 0 & 312,525 & 0 & 0 & 0 & 0 & 0 & 0 & 0 & 312,525 & 312,525 & 0 & 0 & \\
\hline
\end{tabular}

Note: Stream tables are for one train (out of four) of 500 tDM/day 


\subsection{Fast pyrolysis bio-oil stabilization}

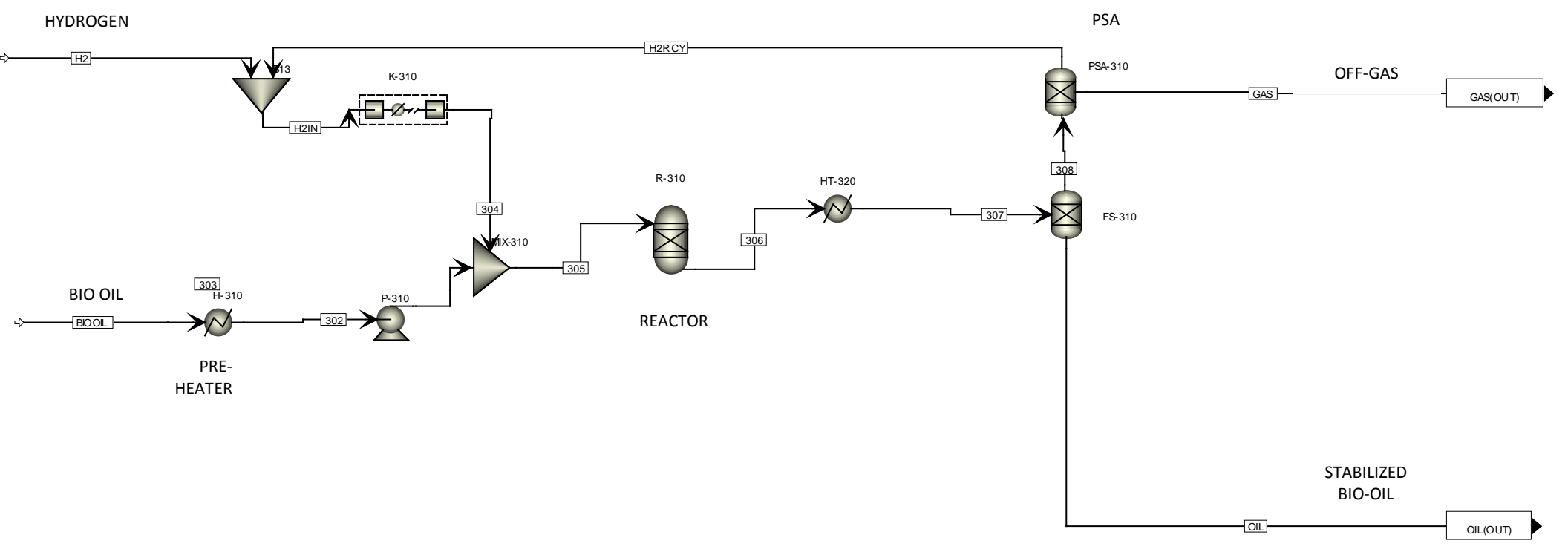




\begin{tabular}{|c|c|c|c|c|c|c|c|c|c|c|c|c|c|}
\hline & BIOOIL & $\mathrm{H} 2$ & $\mathrm{H} 2 \mathrm{IN}$ & 302 & 303 & 304 & 305 & 306 & 307 & 308 & OIL & GAS & $\mathrm{H} 2 \mathrm{RCY}$ \\
\hline Temperature $\mathrm{C}$ & 35 & 40 & 54.9 & 60 & 64.7 & 117.6 & 106.3 & 85 & 60 & 60 & 60 & 60 & 60 \\
\hline Pressure bar & 1.013 & 29.2 & 29.2 & 0.184 & 100 & 137.413 & 100 & 100 & 99 & 99 & 99 & 99 & 99 \\
\hline Volume Flow cum/sec & 0.003 & 0.003 & 0.008 & 0.003 & 0.003 & 0.002 & 0.005 & 0.009 & 0.009 & 0.005 & 0.004 & 0.003 & 0.004 \\
\hline Enthalpy Gcal/hr & -28.054 & 0.001 & 0.007 & -27.834 & -27.793 & 0.021 & -27.772 & -27.566 & -27.841 & -0.873 & -26.975 & -0.88 & 0.012 \\
\hline Mass Flow kg/hr & 14952.3 & 21 & 62.2 & 14952.3 & 14952.3 & 62.2 & 15014.5 & 15014.5 & 15014.5 & 926.319 & 14088.18 & 885.119 & 41.2 \\
\hline $\mathrm{C} 2 \mathrm{H} 4 \mathrm{O}-01$ & 398.416 & & & 398.416 & 398.416 & & 398.416 & 466.051 & 466.051 & & 466.051 & & \\
\hline $\mathrm{C} 2 \mathrm{H} 6 \mathrm{O}-01$ & 19.215 & & & 19.215 & 19.215 & & 19.215 & 19.004 & 19.004 & & 19.004 & & \\
\hline С3H6O-01 & 431.428 & & & 431.428 & 431.428 & & 431.428 & 401.307 & 401.307 & & 401.307 & & \\
\hline $\mathrm{C} 2 \mathrm{H} 4 \mathrm{O}-02$ & 1295.873 & & & 1295.873 & 1295.873 & & 1295.873 & 1886.775 & 1886.775 & & 1886.775 & & \\
\hline C7H8O-01 & 1702.285 & & & 1702.285 & 1702.285 & & 1702.285 & 3373.237 & 3373.237 & & 3373.237 & & \\
\hline $\mathrm{C} 5 \mathrm{H} 4 \mathrm{O}-01$ & 399.125 & & & 399.125 & 399.125 & & 399.125 & 621.36 & 621.36 & & 621.36 & & \\
\hline LEVOGLUC & 4114.329 & & & 4114.329 & 4114.329 & & 4114.329 & 127.635 & 127.635 & & 127.635 & & \\
\hline $\mathrm{CO} 2$ & & & & & & & & 26.29 & 26.29 & 26.29 & & 26.29 & \\
\hline $\mathrm{CH} 4$ & & & & & & & & 267.55 & 267.55 & 267.55 & & 267.55 & \\
\hline $\mathrm{H} 2 \mathrm{O}$ & 4285.093 & & & 4285.093 & 4285.093 & & 4285.093 & 5142.171 & 5142.171 & & 5142.171 & & \\
\hline $\mathrm{CO}$ & & & & & & & & 563.149 & 563.149 & 563.149 & & 563.149 & \\
\hline $\mathrm{H} 2$ & & 21 & 62.2 & & & 62.2 & 62.2 & 51.5 & 51.5 & 51.5 & & 10.3 & 41.2 \\
\hline $\mathrm{C} 2 \mathrm{H} 6-02$ & & & & & & & & 8.801 & 8.801 & 8.801 & & 8.801 & \\
\hline $\mathrm{C} 2 \mathrm{H} 4-02$ & & & & & & & & 9.028 & 9.028 & 9.028 & & 9.028 & \\
\hline C18H3-01 & 1276.9 & & & 1276.9 & 1276.9 & & 1276.9 & 52.177 & 52.177 & & 52.177 & & \\
\hline $\mathrm{C} 4 \mathrm{H} 10-01$ & 16.547 & & & 16.547 & 16.547 & & 16.547 & 16.547 & 16.547 & & 16.547 & & \\
\hline C4H7N-01 & 303.804 & & & 303.804 & 303.804 & & 303.804 & 303.806 & 303.806 & & 303.806 & & \\
\hline PYROLIGN & 709.285 & & & 709.285 & 709.285 & & 709.285 & 1678.11 & 1678.11 & & 1678.11 & & \\
\hline
\end{tabular}

Note: Stream tables are for one train of 500 tDM/day 



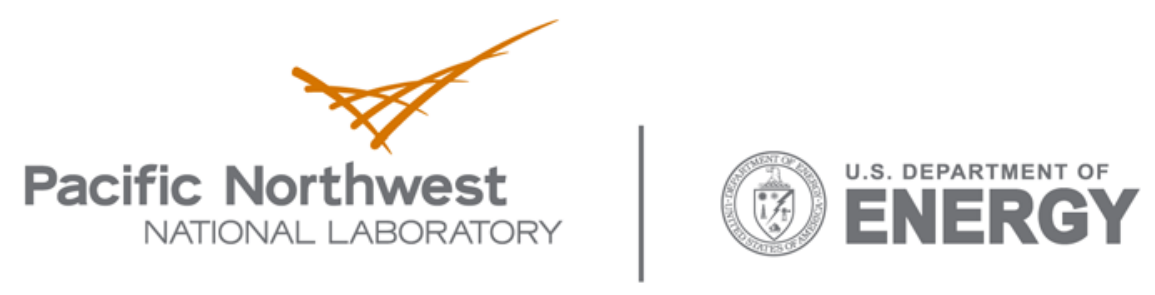

902 Battelle Boulevard

P.O. Box 999

Richland, WA 99352

1-888-375-PNNL (7665)

www.pnl.gov 